\title{
GROWTH AND BIOMASS PRODUCTION OF PRICKLY PEAR IN THE SECOND CYCLE IRRIGATED WITH TREATED DOMESTIC SEWAGE
}

\author{
CRESCIMENTO E PRODUÇÃO DE BIOMASSA DA PALMA FORRAGEIRA \\ SEGUNDO CICLO IRRIGADA COM ESGOTO DOMÉSTICO TRATADO
}

\author{
Manoel Simões de AZEVEDO JUNIOR ${ }^{1}$; Miguel FERREIRA NETO ${ }^{1}$; \\ José Francismar de MEDEIROS ${ }^{1}$; Francisco Vanies da Silva SÁ ${ }^{1}$; Yuri Bezerra de LIMA ${ }^{1}$; \\ Marcírio de LEMOS $^{\mathbf{1}}$; Jorge Luís Fabrício de QUEIROZ $^{\mathbf{1}}$; Rafael Oliveira BATISTA $^{\mathbf{1}}$ \\ 1. Universidade Federal Rural do Semi-Árido, Center of Agrarian Sciences, Mossoró, RN, Brazil. vanies_agronomia@hotmail.com;
}

\begin{abstract}
This study aimed to evaluate, in the second cycle, the growth and production of 'Orelha-de-elefante Mexicana' prickly pear (Opuntia sp.) under complementary irrigation with treated domestic sewage. The experiment was carried out in the Milagre Settlement, municipality of Apodi-RN, Brazil, from June 2016 to February 2017. Five treatments were evaluated, corresponding to four irrigation frequencies (2.3, 7.0, 14.0 and 21.0 days) to apply an effluent depth of $3.5 \mathrm{~mm}$, and the control, rainfed cultivation (without irrigation). The experimental design was randomized blocks, with four replicates. After preliminary-primary treatment, the domestic sewage showed acceptable chemical and physical characteristics for fertigation under the conditions adopted in the prickly pear cultivation. 234 days after the $1^{\text {st }}$ cut in the plants, the following morphometric characteristics were measured: plant height and length, width, perimeter, thickness and number of primary and secondary cladodes, and biomass accumulation. Complementary irrigation with treated domestic sewage effluent applied at intervals of 2.3, 7.0, 14.0 and 21.0 days allowed satisfactory growth and production of 'Orelha-de-elefante Mexicana' prickly pear; without irrigation, its development was substantially hampered during the dry period. Complementary irrigation with $3.5 \mathrm{~mm}$ of domestic sewage effluent applied at intervals of 2.3, 7.0 and 14.0 days led to highest growth and biomass accumulation in 'Orelha-de-elefante Mexicana' prickly pear.
\end{abstract}

KEYWORDS: Irrigation. Forage. Opuntia sp.. Water reuse

\section{INTRODUCTION}

Prickly pear (Opuntia sp. and Nopalea sp.) has high levels of dry matter production per area unit, surpassing native cactuses, which exhibit low yield despite constituting strategic forage reserves in prolonged drought periods (DUBEUX JUNIOR et al., 2015). Brazil is estimated to have approximately 600 thousand hectares of prickly pear, which participates as one of the main foods in various important dairy basins of the Northeast region (DUBEUX JUNIOR et al., 2010).

Prickly pear cultivation increases forage production in rural properties, making them less vulnerable in drought periods. Another positive factor resulting from the increase in forage supply to cattle is related to the reduction in grazing pressure during drought periods, contributing to the preservation of native vegetation (ALMEIDA et al., 2012). When well-managed, the varieties Opuntia and Nopalea can produce 50-60 times more forage per area unit than native pastures in semi-arid environments (DUBEUX JUNIOR. et al., 2015).
In semi-arid regions such as the microregions of Seridó and Sertão Central in the state of Rio Grande do Norte, where the climate conditions do not allow good performance of rainfed prickly pear due to the low relative air humidity, high temperatures at night and high evapotranspiration in the dry period, the use of alternative water sources can reduce these adversities and promote satisfactory development of prickly pear plants, by means of low water depths applied through localized irrigation (LIMA et al., 2015). This management allows for an expansion of the irrigated area with no increase in the demand and higher efficiency in the use of the existing water resources, due to the preservation of more important sources with respect to water quality.

The technologies of domestic sewage treatment used by the sanitation companies become unviable for low-income rural communities, due to the high costs of implementation and maintenance as well as to the dispersion of the population in these communities in semi-arid regions. The current model of social organization implemented by the National Institute of Colonization and Agrarian 
Reform (INCRA) in the agrarian reform settlements presents a proposal of infrastructure for the treatment of domestic sewage in these communities. Therefore, it is necessary to develop low-cost, easily-operated technologies to treat domestic sewage, such as septic tanks, anaerobic filters, flooded system and solar reactors (BATISTA et al., 2011; BATISTA et al., 2013).

Considering the potential of utilization of the effluent, water demand of the crop and especially its yield under semi-arid conditions, this study aimed to evaluate the growth and production of 'Orelha-de-elefante Mexicana' prickly pear in the second year of cultivation under complementary irrigation using treated domestic sewage.

\section{MATERIAL AND METHODS}

The experiment was carried out from June 2016 to February 2017 in the area of the Milagre settlement, rural area of Apodi/RN, Brazil (35' 22" $\mathrm{S} ; 37^{\circ}$ 54' 09” W; $\left.153 \mathrm{~m}\right)$. According to Köppen's classification, the climate of the region is BSw'h', characterized as very hot and semi-arid, with rainy season in the summer and autumn. Meteorological data of 2015, 2016 and 2017 are presented in Table 1.

The settlement has a model structure for collection and treatment, in primary stage, of domestic effluents. The sewage treatment station (STS) is located in an agricultural area of collective use by the community and processes all the effluent collected from 28 households situated in the agrovillage of the settlement. The sewage moves by gravity to the treatment station, where it undergoes a preliminary/primary treatment called decanterdigester. The system comprises a septic tank with two chambers and two downflow anaerobic filters. After exiting the station, the effluent moves by gravity to two cisterns with combined capacity for $70,000 \mathrm{~L}$, which are used to irrigate the community's agricultural area. The STS was dimensioned to treat a volume of $20 \mathrm{~m}^{3}$ of sewage per day.

Table 1. Meteorological data collected at the Automatic Station of the INMET in Apodi/RN.

\begin{tabular}{llllllllll}
\hline Year & 2016 & \multicolumn{1}{c}{} & \multicolumn{4}{c}{2017} \\
\hline Months & Jun & Jul & Aug & Sep & Oct & Nov & Dec & Jan & Feb \\
\hline Rains (mm) & 0.1 & 0.0 & 0.0 & 0.0 & 0.0 & 0.0 & 54.4 & 15.3 & 217.7 \\
Max. Temperature $\left({ }^{\circ} \mathrm{C}\right)$ & 34.4 & 34.3 & 35.1 & 35.9 & 36.5 & 36.7 & 35.8 & 35.8 & 33.9 \\
Min. Temperature $\left({ }^{\circ} \mathrm{C}\right)$ & 23.9 & 23.5 & 23.2 & 24.2 & 24.0 & 24.2 & 24.6 & 24.9 & 24.4 \\
Mean RH (\%) & 62.3 & 57.2 & 58.7 & 65.0 & 64.5 & 68.3 & 67.6 & 59.9 & 67.4 \\
Mean wind speed (mps) & 2.4 & 3.4 & 2.9 & 2.6 & 2.7 & 2.5 & 2.3 & 2.3 & 1.7 \\
Insolation (h) & 274.4 & 284.1 & 331.7 & 322.2 & 323.5 & 317.7 & 254.3 & 284.6 & 249.0 \\
ETo (mm) & 165.8 & 169.4 & 171.0 & 174.8 & 198.6 & 199.6 & 196.4 & 204.0 & 157.0 \\
\hline
\end{tabular}

INMET- National Institute of Meteorology

Prickly pear - Opuntia sp., variety 'Orelhade-elefante Mexicana', was planted in October 2013 in a $2,205-\mathrm{m}^{2}$ area whose soil was classified as Argissolo Vermelho Amarelo (Ultisol) (EMBRAPA, 2013). The first experiment (LEMOS et al., 2018) aimed to evaluate prickly pear production and the physical and chemical impacts caused by the accumulation of nutrients in the soil and in the plant subjected to irrigation with treated domestic sewage, at 4 different intervals between irrigation events, with fixed depth of $3.5 \mathrm{~mm}$ per event and 3 planting densities. The second experiment, after the second cut, evaluated the performance of prickly pear plants under complementary irrigation with treated domestic sewage at 4 different irrigation intervals and the chemical impacts on the soil and on the plants, based on the effluent treatment efficiency and water quality for irrigation.

Water was applied using a localized irrigation system, through 16-mm-diameter polyethylene lines spaced by $3 \mathrm{~m}$ and $5-\mathrm{mm}$ - diameter microtube emitters with nominal flow rate of $80 \mathrm{~L} \mathrm{~h}^{-1}$ spaced by $2.5 \mathrm{~m}$. The irrigation system called "modified bubbler" derives from the American bubbler system and was installed to distribute the water at low pressure and in $2.5-\mathrm{m}$ long small leveled furrows. After being pumped by a 1.0-hp electric pump to a 1000 -L plastic tank located in the middle of the planting area at height of $1.5 \mathrm{~m}$, the effluent was distributed by gravity to the irrigation furrows through 16-mm-diameter polyethylene hoses.

The "modified bubbler" system has the advantages of using low-cost equipment, saving energy and reducing problems related to emitter clogging, as observed in drip systems when used for irrigation with effluent (HAO et al., 2017). The water depth applied in each irrigation was $3.5 \mathrm{~mm}$, which corresponds to half of the mean daily ETo historically recorded in years prior to the experiment. This depth was selected according to Lemos et al. (2018). Table 2 presents the amounts of 
treated domestic sewage effluent applied through

experiment. irrigation in the prickly pear crop along the

Table 2. Amount of treated domestic sewage effluent applied through irrigation in the prickly pear crop along the experiment

\begin{tabular}{|c|c|c|c|c|c|c|}
\hline Treatments & $\begin{array}{l}\text { Depth applied by } \\
\text { irrigation } \\
(\mathrm{mm})\end{array}$ & $\begin{array}{l}\text { Irrigation } \\
\text { Days }\end{array}$ & $\begin{array}{l}\text { Total depth applied } \\
\text { in cycle }(\mathrm{mm})\end{array}$ & $\begin{array}{l}\text { Volume per } \\
\text { hectare } \\
\left(\mathrm{m}^{3} \mathrm{ha}^{-1}\right)\end{array}$ & $\begin{array}{l}\text { Average } \\
\text { monthly volume } \\
\left(\mathrm{m}^{3} \mathrm{ha}^{-1}\right)\end{array}$ & $\begin{array}{l}\text { Average daily } \\
\text { volume } \\
\left(\mathrm{m}^{3} \mathrm{ha}^{-1}\right)\end{array}$ \\
\hline 2.3 Days & 3.5 & 93 & 325.5 & 3,255 & 465 & 15.5 \\
\hline 7.0 Days & 3.5 & 32 & 112 & 1,120 & 160 & 5.3 \\
\hline 14.0 Days & 3.5 & 16 & 56 & 560 & 80 & 2.7 \\
\hline 21.0 Days & 3.5 & 10 & 35 & 350 & 50 & 1.7 \\
\hline $\begin{array}{l}\text { rainfed } \\
\text { cultivation }\end{array}$ & - & - & - & - & - & - \\
\hline
\end{tabular}

The experimental design was randomized blocks, with 5 treatments and 4 replicates, totaling 20 plots, which were converted as such by using the central subplots of the previous experiment, preserving the original design of the area. The number of plants per plot was standardized to leave 12 plants on each side of the irrigation furrow, totaling 24 plants irrigated by the same furrow. Thus, the spacing between plants was standardized as $0.20 \mathrm{~m}$, equivalent to the double-row spacing of $2.2 \times 0.8 \times 0.2 \mathrm{~m}\left(33.333\right.$ plants $\left.\mathrm{ha}^{-1}\right)$.

Treatments consisted of irrigation with treated domestic sewage, applying a fixed depth of $3.5 \mathrm{~mm}$ at four different intervals $(\mathrm{T} 1=2.3$ days, $\mathrm{T} 2$ $=7$ days, $\mathrm{T} 3=14$ days and $\mathrm{T} 4=21$ days), and one absolute control $(\mathrm{T} 5=$ cultivation without irrigation).
Irrigation with effluent resumed in July 2016 and followed an irrigation calendar according to the intervals established, extending up to February 2017, when the field research ended. Cactus scale (Diaspis echinocacti) was controlled using $250 \mathrm{~mL}$ of cotton oil and $150 \mathrm{~mL}$ of neutral detergent diluted in $10 \mathrm{~L}$ of water, applied every two weeks. Weeds were controlled by manual weeding using a hoe always when necessary.

To evaluate the fertility of the soil cultivated with prickly pear under fertigation with treated domestic sewage effluent for a period of 234 days after the second cut, soil samples were collected in the $0-20 \mathrm{~cm}$ layer and analyzed according to the methodology recommended by Donagema et al. (2011) (Table 3).

Table 3. Analysis results for the soil samples collected 234 days after fertigation with treated domestic sewage, in the second year of production.

\begin{tabular}{|c|c|c|c|c|c|}
\hline \multirow{2}{*}{ Attributes } & \multicolumn{4}{|c|}{ Days } & \multirow[b]{2}{*}{ without irrigation } \\
\hline & 2.3 & 7 & 14 & 21 & \\
\hline $\mathrm{N}(\mathrm{g} / \mathrm{kg})$ & 0.63 & 0.35 & 0.56 & 0.28 & 0.63 \\
\hline $\mathrm{pH}$ (water) & 5.22 & 5.40 & 6.00 & 6.25 & 4.97 \\
\hline $\mathrm{EC}\left(\mathrm{dS} \mathrm{m}^{-1}\right)$ & 0.13 & 0.09 & 0.08 & 0.11 & 0.19 \\
\hline $\mathrm{OM}\left(\mathrm{g} \mathrm{kg}^{-1}\right)$ & 5.20 & 6.24 & 6.24 & 5.20 & 4.99 \\
\hline $\mathrm{P}\left(\mathrm{mg} \mathrm{dm}^{-3}\right)$ & 50.60 & 87.00 & 48.00 & 73.80 & 60.60 \\
\hline $\mathrm{K}^{+}\left(\mathrm{mg} \mathrm{dm}{ }^{-3}\right)$ & 57.60 & 81.90 & 66.70 & 62.70 & 66.70 \\
\hline $\mathrm{Na}^{+}\left(\mathrm{mg} \mathrm{dm}^{-3}\right)$ & 108.50 & 78.60 & 57.60 & 68.60 & 10.80 \\
\hline $\mathrm{Ca}^{2+}\left(\mathrm{cmol}_{\mathrm{c}} \mathrm{dm}^{-3}\right)$ & 1.59 & 1.35 & 1.66 & 1.51 & 2.37 \\
\hline $\mathrm{Mg}^{2+}\left(\mathrm{cmol}_{\mathrm{c}} \mathrm{dm}^{-3}\right)$ & 2.21 & 3.22 & 2.32 & 2.56 & 1.73 \\
\hline $\mathrm{Al}^{3^{+}}\left(\mathrm{cmol}_{\mathrm{c}} \mathrm{dm}^{-3}\right)$ & 0.50 & 0.81 & 0 & 0 & 0.75 \\
\hline $\mathrm{H}+\mathrm{Al}\left(\mathrm{cmol}_{\mathrm{c}} \mathrm{dm}^{-3}\right)$ & 4.13 & 4.79 & 3.14 & 2.64 & 3.30 \\
\hline $\mathrm{SB}\left(\mathrm{cmol}_{\mathrm{c}} \mathrm{dm}^{-3}\right)$ & 4.42 & 5.12 & 4.40 & 4.53 & 4.32 \\
\hline $\mathrm{T}\left(\mathrm{cmol}_{\mathrm{c}} \mathrm{dm}^{-3}\right)$ & 4.92 & 5.93 & 4.40 & 4.53 & 5.07 \\
\hline $\operatorname{CEC}\left(\mathrm{cmol}_{\mathrm{c}} \mathrm{dm}^{-3}\right)$ & 8.54 & 9.91 & 7.54 & 7.17 & 7.62 \\
\hline V $(\%)$ & 52.00 & 52.00 & 58.00 & 63.00 & 57.00 \\
\hline $\mathrm{m}(\%)$ & 10.00 & 14.00 & 0 & 0 & 15.00 \\
\hline $\operatorname{ESP}(\%)$ & 6.00 & 3.00 & 3.00 & 4.00 & 1.00 \\
\hline $\mathrm{Cu}^{2+}\left(\mathrm{mg} \mathrm{dm}^{-3}\right)$ & 0.82 & 0.54 & 0.52 & 0.51 & 0.87 \\
\hline $\mathrm{Fe}^{3+}\left(\mathrm{mg} \mathrm{dm}^{-3}\right)$ & 5.52 & 7.32 & 4.95 & 6.23 & 5.69 \\
\hline $\mathrm{Mn}^{3+}\left(\mathrm{mg} \mathrm{dm}^{-3}\right)$ & 118.95 & 91.4 & 123.85 & 118.85 & 121.95 \\
\hline $\mathrm{Zn}^{2+}\left(\mathrm{mg} \mathrm{dm}^{-3}\right)$ & 1.20 & 1.31 & 1.88 & 1.77 & 1.98 \\
\hline
\end{tabular}

Treatments: irrigation frequencies of 2.3, 7.0, 14.0 and 21.0 days, and rainfed control. 
Approximately every 30 days, from September to December 2016, domestic sewage samples were collected for chemical and biological analyses at three points located before and after the STS. The first collection point was located before the STS; the second point was located after the STS and the third point was located in the reservoir used to accumulate the effluent for irrigation, after the STS (Table 4).

Table 4. Mean values of chemical and biological characteristics of the effluent samples.

\begin{tabular}{llllllll}
\hline Characteristics & Point 1 & SD & Point 2 & SD & Point 3 & SD & Removal (\%) \\
\hline $\mathrm{pH}(\mathrm{water})$ & 7.07 & \pm 0.17 & 6.90 & \pm 0.33 & 7.40 & \pm 0.43 & - \\
$\mathrm{EC}(\mathrm{dS} / \mathrm{m})$ & 1.03 & \pm 0.15 & 1.12 & \pm 0.16 & 1.09 & \pm 0.15 & - \\
$\mathrm{K}^{+}(\mathrm{mmolc} / \mathrm{L})$ & 0.72 & \pm 0.13 & 0.71 & \pm 0.09 & 0.70 & \pm 0.10 & - \\
$\mathrm{Na}^{+}(\mathrm{mmolc} / \mathrm{L})$ & 3.16 & \pm 0.94 & 3.30 & \pm 0.48 & 3.26 & \pm 0.54 & - \\
$\mathrm{Ca}^{2+}(\mathrm{mmolc} / \mathrm{L})$ & 0.97 & \pm 0.22 & 0.87 & \pm 0.09 & 0.92 & \pm 0.09 & - \\
$\mathrm{Mg}^{2+}(\mathrm{mmolc} / \mathrm{L})$ & 1.75 & \pm 1.10 & 2.12 & \pm 1.19 & 1.92 & \pm 1.11 & - \\
$\mathrm{Cl}^{-}(\mathrm{mmolc} / \mathrm{L})$ & 3.75 & \pm 0.97 & 3.50 & \pm 1.22 & 3.55 & \pm 1.21 & - \\
$\mathrm{HCO}_{3}(\mathrm{mmolc} / \mathrm{L})$ & 6.77 & \pm 1.46 & 6.60 & \pm 1.56 & 6.70 & \pm 1.00 & - \\
$\mathrm{P}^{+}(\mathrm{mg} / \mathrm{L})$ & 6.73 & \pm 2.04 & 7.85 & \pm 1.59 & 7.82 & \pm 0.95 & - \\
$\mathrm{NH}_{4}^{+}-\mathrm{N}(\mathrm{mg} / \mathrm{L})$ & 28.58 & \pm 11.92 & 31.56 & \pm 7.46 & 29.91 & \pm 9.29 & - \\
$\mathrm{NO}{ }^{-}-\mathrm{N}(\mathrm{mg} / \mathrm{L})$ & 15.88 & \pm 24.25 & 2.14 & \pm 3.31 & 14.58 & \pm 18.73 & 8.19 \\
$\mathrm{SAR}(\mathrm{mg} / \mathrm{L})$ & 2.85 & \pm 1.04 & 2.77 & \pm 0.41 & 2.80 & \pm 0.48 & 1.76 \\
$\mathrm{BOD}(\mathrm{mg} / \mathrm{L})$ & 258.5 & \pm 103.48 & 41.50 & \pm 5.80 & 18.75 & \pm 10.90 & 92.75 \\
$\mathrm{COD}(\mathrm{mg} / \mathrm{L})$ & 618 & \pm 231.82 & 143.00 & \pm 5.41 & 94.00 & \pm 10.80 & 84.79 \\
$\mathrm{TOG}(\mathrm{ppm})$ & 19.43 & \pm 23.21 & 19.77 & \pm 36.21 & 1.81 & \pm 3.32 & 90.68 \\
$\mathrm{Cu}(\mathrm{mg} / \mathrm{L})$ & 0.08 & \pm 0.003 & 0.08 & \pm 0.01 & 0.08 & \pm 0.005 & - \\
$\mathrm{Mn}(\mathrm{mg} / \mathrm{L})$ & 0.06 & \pm 0.027 & 0.04 & \pm 0.03 & 0.08 & \pm 0.009 & - \\
$\mathrm{Fe}(\mathrm{mg} / \mathrm{L})$ & 0.42 & \pm 0.267 & 0.22 & \pm 0.031 & 0.24 & \pm 0.018 & - \\
$\mathrm{Zn}(\mathrm{mg} / \mathrm{L})$ & 0.05 & \pm 0.017 & 0.03 & \pm 0.004 & 0.05 & \pm 0.041 & - \\
$\mathrm{Ni}(\mathrm{mg} / \mathrm{L})$ & 0.00 & \pm 0.00 & 0.00 & \pm 0.00 & 0.00 & \pm 0.000 & - \\
$\mathrm{Cd}(\mathrm{mg} / \mathrm{L})$ & 0.00 & \pm 0.00 & 0.00 & \pm 0.00 & 0.00 & \pm 0.000 & - \\
$\mathrm{Pb}(\mathrm{mg} / \mathrm{L})$ & 0.05 & \pm 0.075 & 0.17 & \pm 0.12 & 0.03 & \pm 0.075 & - \\
\hline
\end{tabular}

Mean values (of the points 1, 2 and 3) and SD - Standard deviation ( \pm )

After periods of 110,170 and 230 days from the second cut (October/2016, December/2016 and February/2017, respectively), growth parameters were measured in five prickly pear plants representative of each plot, which were randomly selected and identified. The following morphometric parameters were analyzed: plant height $(\mathrm{PH})$, number of cladodes (NC) (primary and secondary), cladode length $(\mathrm{CL})$, cladode width $(\mathrm{CW})$, cladode thickness (CT) and cladode perimeter (CP). A tape measure was used in the measurements of plant height and cladode length, width and perimeter, whereas a digital caliper was used to measure cladode thickness.

In February 2017, in addition to collecting data of growth parameters, the five plants selected at the beginning of the study were harvested and weighed, leaving their main stems at the field for future regrowth. Therefore, five prickly pear plants were harvested in each plot, totaling 20 plants per treatment, to obtain the green matter (GM), expressed in kilograms. Green matter and plant density data were used to calculate the green matter in kilograms per hectare.

The data were subjected to analysis of variance and treatment means were compared by
Tukey test at 0.05 probability level. Statistical analyses were carried out using the computer program SISVAR, version 5.3 (FERREIRA, 2014).

\section{RESULTS AND DISCUSSION}

There was no significant difference in the number of primary cladodes (NPC) between treatments (Table 5) according to the counts at 110 and 170 days after the second cut (DASC), with 5.27 and 5.28 primary cladodes per plant, respectively. However, at 234 DASC there was a significant difference in NPC as a function of the irrigation frequencies, and only plants irrigated every seven days had significant growth compared with those without irrigation. Between irrigation intervals, there was no significant difference in the NPC after the three periods evaluated. Although the difference in the NPC between counts at the beginning and end of the study was not significant, this parameter tended to increase over time. The same was reported by Ramos et al. (2015), who observed linear increase in the total number of cladodes over time, which suggests greater interval between production cycles when the purpose is to produce higher number of cladodes. 
Table 5. Morphometric characteristics of prickly pear: number of primary cladodes-NPC, number of secondary cladodes-NSC, plant height-PH, cladode length-CL, cladode width-CW, cladode thickness-CT and cladode perimeter- $\mathrm{CP}$, under different frequencies of irrigation with treated domestic sewage.

\begin{tabular}{|c|c|c|c|c|c|c|c|}
\hline \multirow{2}{*}{ Treatments } & \multicolumn{7}{|c|}{ Variables analyzed } \\
\hline & NPC & $\mathrm{NSC}$ & $\mathrm{PH}$ & $\mathrm{CL}$ & $\mathrm{CW}$ & $\mathrm{CT}$ & $\mathrm{CP}$ \\
\hline & Unit & Unit & $\mathrm{cm}$ & \multicolumn{2}{|c|}{ ….................. } & \multicolumn{2}{|c|}{ …................... } \\
\hline \multicolumn{8}{|c|}{110 DASC } \\
\hline 2.3 Days & $5.0 \mathrm{a}$ & - & $42.0 \mathrm{a}$ & $25.5 \mathrm{a}$ & $13.3 \mathrm{a}$ & $0.8 \mathrm{a}$ & $60.5 \mathrm{a}$ \\
\hline 7.0 Days & $6.2 \mathrm{a}$ & - & $42.1 \mathrm{a}$ & $23.7 \mathrm{ab}$ & $12.7 \mathrm{a}$ & $0.7 \mathrm{~b}$ & $56.5 \mathrm{ab}$ \\
\hline 14.0 Days & $5.5 \mathrm{a}$ & - & $41.4 \mathrm{a}$ & $22.8 \mathrm{~b}$ & $12.0 \mathrm{ab}$ & $0.5 \mathrm{c}$ & $54.0 \mathrm{~b}$ \\
\hline 21.0 Days & $6.2 \mathrm{a}$ & - & $37.5 \mathrm{a}$ & $19.7 \mathrm{c}$ & $10.4 \mathrm{~b}$ & $0.3 \mathrm{~d}$ & $47.0 \mathrm{c}$ \\
\hline rainfed cultivation & $3.3 \mathrm{a}$ & - & $27.6 \mathrm{~b}$ & $11.2 \mathrm{~d}$ & $7.4 \mathrm{c}$ & $0.1 \mathrm{e}$ & $28.8 \mathrm{~d}$ \\
\hline Mean & 5.27 & - & 38.15 & 20.62 & 11.21 & 0.5 & 49.4 \\
\hline CV (\%) & 24.08 & - & 8.17 & 5.52 & 7.09 & 6.77 & 5.30 \\
\hline \multicolumn{8}{|c|}{170 DASC } \\
\hline 2.3 Days & $5.0 \mathrm{a}$ & $3.0 \mathrm{a}$ & $46.9 \mathrm{a}$ & $26.1 \mathrm{a}$ & $14.0 \mathrm{a}$ & $0.9 \mathrm{a}$ & $62.7 \mathrm{a}$ \\
\hline 7.0 Days & $6.2 \mathrm{a}$ & $0.3 \mathrm{~b}$ & $43.0 \mathrm{a}$ & $24.5 \mathrm{ab}$ & $13.2 \mathrm{ab}$ & $0.7 \mathrm{~b}$ & $58.7 \mathrm{ab}$ \\
\hline 14.0 Days & $5.5 \mathrm{a}$ & $1.0 \mathrm{~b}$ & $41.6 \mathrm{a}$ & $23.1 \mathrm{bc}$ & $12.4 \mathrm{ab}$ & $0.6 \mathrm{bc}$ & $54.3 \mathrm{bc}$ \\
\hline 21.0 Days & $6.1 \mathrm{a}$ & $0.0 \mathrm{~b}$ & $39.9 \mathrm{a}$ & $21.4 \mathrm{c}$ & $11.6 \mathrm{~b}$ & $0.5 \mathrm{c}$ & $51.6 \mathrm{c}$ \\
\hline rainfed cultivation & $3.5 \mathrm{a}$ & $0.0 \mathrm{~b}$ & $27.7 \mathrm{~b}$ & $10.9 \mathrm{~d}$ & $7.4 \mathrm{c}$ & $0.2 \mathrm{~d}$ & $28.1 \mathrm{~d}$ \\
\hline Mean & 5.28 & 0.89 & 39.84 & 21.24 & 11.77 & 0.6 & 51.1 \\
\hline CV (\%) & 22.94 & 10.13 & 8.72 & 5.50 & 5.89 & 11.70 & 4.75 \\
\hline \multicolumn{8}{|c|}{234 DASC } \\
\hline 2.3 Days & $5.3 \mathrm{ab}$ & $8.0 \mathrm{a}$ & $62.0 \mathrm{a}$ & $26.9 \mathrm{a}$ & $14.7 \mathrm{a}$ & $1.1 \mathrm{a}$ & $64.4 \mathrm{a}$ \\
\hline 7.0 Days & $6.4 \mathrm{a}$ & $8.4 \mathrm{a}$ & $62.2 \mathrm{a}$ & $27.1 \mathrm{a}$ & $15.5 \mathrm{a}$ & $0.7 \mathrm{~b}$ & $64.8 \mathrm{a}$ \\
\hline 14.0 Days & $5.8 \mathrm{ab}$ & $9.3 \mathrm{a}$ & $58.1 \mathrm{a}$ & $27.4 \mathrm{a}$ & $15.4 \mathrm{a}$ & $0.6 \mathrm{bc}$ & $64.0 \mathrm{a}$ \\
\hline 21.0 Days & $6.2 \mathrm{ab}$ & $7.1 \mathrm{a}$ & $55.3 \mathrm{a}$ & $24.8 \mathrm{a}$ & $14.1 \mathrm{a}$ & $0.5 \mathrm{~cd}$ & $60.1 \mathrm{a}$ \\
\hline rainfed cultivation & $3.6 \mathrm{~b}$ & $0.7 \mathrm{~b}$ & $31.0 \mathrm{~b}$ & $16.7 \mathrm{~b}$ & $15.3 \mathrm{a}$ & $0.4 \mathrm{~d}$ & $41.6 \mathrm{~b}$ \\
\hline Mean & 5.48 & 6.74 & 53.75 & 24.60 & 15.05 & 0.7 & 59.0 \\
\hline CV (\%) & 21.9 & 16.44 & 11.72 & 8.14 & 10.43 & 8.30 & 7.03 \\
\hline
\end{tabular}

* Means followed by the same letters in the columns do not differ by Tukey test at 0.05 probability level.

From 170 DASC, secondary cladodes were observed in the plants of treatments irrigated at intervals of 2.3, 7.0 and 14.0 days, whereas plants irrigated every 21 days and without irrigation did not have secondary cladodes. In this period, the treatment irrigated every 2.3 days showed NSC significantly higher than those of the others (Table 5). Irrigation led to changes in the growth dynamics of the prickly pear plant. Other studies point that the additional water supply can be an interesting strategy to establish the prickly pear plantation with the increase in yield (REGO et al., 2014; QUEIROZ et al., 2015).

Secondary cladodes were observed in the plants of all treatments only at 234 DASC. Normally, in rain-dependent areas the cut of prickly pear is performed two to four years after planting (ALMEIDA et al., 2012).

Irrigated plants showed NSC significantly higher compared with the control, regardless of irrigation intervals. According to Queiroz et al. (2015), prickly pear produces first- and secondorder cladodes more rapidly when irrigated, demonstrating that the efficiency in water use by the plant leads to increase in its growth and development. According to Rocha et al. (2017), when prickly pear is cultivated under irrigation and fertilization, plants already have considerable values of forage mass at the cut performed four months after planting. Short intervals will promote greater sustainability and maintenance of the herd.

The mean values of plant height in irrigated treatments were statistically superior to those of the rainfed control in all periods analyzed $(110,170$ and 234 DASC). There was a small variation in mean plant height between the periods of 110 and 170 days, which was proportionally lower than the variation observed between 170 and 234 days. Over the time of cultivation, these differences become more evident and are justified by the continuous supply of water and nutrients to plants along the entire cycle.

Similar results were found by Lemos et al. (2018) and Rocha et al. (2017), in the first cultivation cycle. These authors observed that changes in prickly pear growth are slow in the initial stage of cultivation for all variables studied. 
Cladode length increased over time, with mean values of 20.62, 21.24 and $24.60 \mathrm{~cm}$ at 110 , 170 and 234 DASC, respectively. At 110 and 170 DASC, there were significant differences between irrigated treatments and between irrigated treatments and the rainfed control; plants irrigated every 2.3 days showed the highest values of cladode length. Nevertheless, at 234 DASC, all irrigated treatments showed cladode lengths statistically similar to one another and superior to that of the rainfed control.

The cladode length of 'Orelha-de-elefante Mexicana' prickly pear, evaluated in the present study, when irrigated, was similar to that found by Silva et al. (2014) for 'Gigante' prickly pear. However, when prickly pear was grown under rainfed conditions in the present study, cladode length was lower than that found be these authors for 'Miúda' prickly pear. The data of irrigated prickly pear also corroborate those reported by Rocha et al. (2017), evaluating 'Orelha-de-elefante Mexicana' prickly pear in different harvest periods.

Cladode width response was similar to that of cladode length, with respect to the increase in the dimensions over time, showing mean values of $11.21,11.77$ and $15.05 \mathrm{~cm}$, at 110,170 and 234 DASC, respectively (Table 5). According to Lemos et al. (2018), there is a direct relationship between cladode width and length in the initial growth stage of prickly pear, when the cladode elongates longitudinally and transversely at the same time.

According to the data of cladode width (Table 5), there was significant difference between the means of irrigated treatments and between irrigated treatments and the rainfed control at 110 and 170 DASC. Already at these two periods, irrigated treatments were statistically superior to the rainfed control and showed small variations, although irrigated plants differed regarding cladode width between irrigation intervals.

At 234 DASC, there was a sharp increase in cladode length in plants without irrigation, which even became statistically similar to irrigated plants. This phenomenon was caused by the rains that occurred in December/2016 and January/2017, which contributed to the fast growth of prickly pear plants under rainfed conditions. This reveals a high potential of resilience with respect to the semi-arid environment. The mean cladode width of $15.05 \mathrm{~cm}$ observed at 234 DASC in the present study is similar to the value of $15.63 \mathrm{~cm}$ found by Souto et al. (2011) at 330 days after planting for prickly pear cultivated at a smaller spacing $(1.7 \times 0.25 \mathrm{~m})$.

Mean cladode thickness was equal to 0.5 , 0.6 and $0.7 \mathrm{~cm}$ at 110,170 and 234 DASC, respectively. At the three measurements, there were significant differences between treatments (Table 5). At 110 DASC, all treatments differed statistically, following an order in which the treatment which received more water had greater cladode thickness than that which received less water, i.e., irrigation applied every 2.3 days $>7$ days $>14$ days $>21$ days $>$ rainfed cultivation.

Similar results were obtained by Lemos et al. (2018), who found a trend of greater thickness in cladodes of plants which received greater amount of water, at 75 DAP. Likewise, the measurements taken at 170 and 234 DASC demonstrated that the means of the treatments, either with or without significant differences, followed the same trend in which plants receiving a larger volume of water showed greater cladode thickness.

Mean cladode perimeter was equal to 49.4 , 51.1 and $59.0 \mathrm{~cm}$ at 110,170 and 234 DASC, respectively. At the three measurements, the means were significantly higher in irrigated treatments compared with the rainfed control (Table 5). This demonstrates that, under the conditions of the present study, irrigation with treated domestic effluent leads to greater growth and development in prickly pear plants.

At 110 and 170 DASC, treatments irrigated with treated sewage effluent differed from one another, which did not occur at 234 DASC, when irrigated treatments showed statistically similar means. At 110 and 170 DASC, treatments irrigated at frequencies of 2.3 and 7 days were statistically superior to that irrigated every 21 days (Table 5).

As for the other morphometric characteristics analyzed, treatments that received greater volumes of water showed higher mean values of cladode parameter, in comparison to those irrigated with smaller volumes. Such situation corroborates the observation made by Ramos et al. (2015), that prickly pear vegetative growth is strongly related to soil water content, because the main physiological and biochemical processes depend on water.

The green matter per plant (GM) was significantly influenced by the irrigation with treated domestic sewage effluent at different frequencies. Biomass accumulation in plants irrigated every 2.3, 7 and 14 days was 6.6, 6.5 and 5.2 times higher than in rainfed plants, respectively. The treatment irrigated every 21 days, despite not differing from the other irrigated treatments, also did not differ statistically from the absolute control (Table 6). Strategically, the effects of irrigation intervals greater 14 days can only be noticed in 
periods of extreme water demand by the crop, comprehended by the dry season.

Table 6. Mean values of green matter (GM) of prickly pear cladodes at 234 days after the second cut.

\begin{tabular}{lll}
\hline \multirow{2}{*}{ Treatments } & $\mathrm{GM}$ \\
\cline { 2 - 3 } & $\mathrm{kg} \mathrm{pl}^{-1}$ & $\mathrm{~kg} \mathrm{ha}^{-1}$ \\
\hline 2.3 Days & $2.707 \mathrm{a}$ & 90,232 \\
7.0 Days & $2.678 \mathrm{a}$ & 89,265 \\
14.0 Days & $2.123 \mathrm{a}$ & 70,765 \\
21.0 Days & $1.518 \mathrm{ab}$ & 50,599 \\
rainfed cultivation & $0.411 \mathrm{~b}$ & 13,699 \\
\hline Mean & 1.88 & 62,912 \\
\hline CV $(\%)$ & 29.05 & \\
\hline
\end{tabular}

* Means followed by the same letter in the columns do not differ by Tukey test at 0.05 probability level.

The same observation was made by Lemos et al. (2018), in the first cycle, in which the highest values green matter production were proportional to the highest effluent depths applied. According to Scalisi et al. (2016), for cladode growth to occur, the prickly pear plant needs relative water content of $45 \%$. Prickly pear has CAM metabolism for the synthesis of tissues, which involves stomatal opening during the nighttime, fixing $\mathrm{CO}_{2}$ in this period when organic acids are accumulated in the cytosol (ROCHA et al., 2017). In other words, as water was supplied to the plant, its growth rate increased and it consequently used this resource better for its development.

The mean values of $2.71,2.68$ and $2.12 \mathrm{~kg}$ plant $^{-1}$ obtained in plants irrigated at frequencies of 2.3, 7 and 14 days were higher than those observed by Edivan et al. (2013), working with the prickly pear clone IPA 20 under irrigation in different harvest periods, until 335 days after planting.

Since the estimate of green matter production per hectare was proportional to the values of green matter production per plant, consequently the greater green matter production per hectare was observed at the highest irrigation frequency ( 2.3 days), followed by the frequencies of 7, 14 and 21 days, respectively, and by the production under rainfed conditions, all obtained at 234 days after the second cut. The highest mean value of green matter production per hectare ( 90.232 t) obtained in the present experiment at 234 DASC was close to the mean production of prickly pear estimated by Souto et al. (2011). These authors obtained the highest green matter production per hectare at 330 days after planting (92.79 t), evaluating different population arrangements and phosphorus doses. The yield obtained in the present study was 4 times higher than that reported by Souza et al. (2017), who worked with 'Miúda' prickly pear at density of 40,000 thousand plants per hectare.

The results obtained here indicate that effluent from treated domestic sewage has potential to be used to irrigate prickly pear under semi-arid conditions and is a low-cost water source which reduces impacts on the environment. This same finding has also been reported for corn (COSTA et al., 2014), cowpea (REBOUÇAS et al., 2010), rice (BRITO et al., 2014) and sunflower (ALVES et al., 2014).

\section{CONCLUSIONS}

'Orelha-de-elefante Mexicana' prickly pear plants in the semi-arid region of Brazil, without irrigation, do not have satisfactory growth and production during the dry period.

Complementary irrigation with $3.5 \mathrm{~mm}$ of treated sewage effluent, regardless of the application interval allowed satisfactory growth and production of 'Orelha-de-elefante Mexicana' prickly pear in the semi-arid region of Brazil.

Complementary irrigation with $3.5 \mathrm{~mm}$ of domestic sewage effluent applied at intervals of 2.3, 7.0 and 14.0 days led to highest growth and biomass accumulation in 'Orelha-de-elefante Mexicana' prickly pear.

RESUMO: Objetivou-se com esse trabalho avaliar, no segundo ciclo, o crescimento e a produção da palma forrageira orelha-de-elefante (Opuntia sp), conduzida sob irrigação complementar, com esgoto doméstico tratado. O experimento foi realizado no Assentamento Milagre, município de Apodi/RN, no período 
de junho/2016 a fevereiro/2017. Foram estudados cinco tratamentos, sendo quatro frequências de irrigação (2,3; 7; 14 e 21 dias), para aplicar uma lâmina de $3,5 \mathrm{~mm}$ de efluente, e a testemunha, cultivo em sequeiro (sem irrigação). Utilizou-se o delineamento de blocos casualizados com quatro repetições. A água de esgoto doméstico após passar pelo tratamento preliminar-primário apresentou características químicas e biológicas aceitáveis para a fertirrigação nas condições utilizadas no cultivo da palma. Após 234 dias do $1^{\circ}$ corte realizado na palma, foram feitas medições das características morfométricas: altura de planta, comprimento, largura, perímetro, espessura e número de cladódios primário e secundário e acúmulo de biomassa. A complementação hídrica realizada por irrigação com intervalos de 2,3;7,0;14,0 e 21,0 dias, viabilizou satisfatoriamente o crescimento e a produção da palma forrageira orelha de elefante que, sem irrigação, teve seu desenvolvimento bastante comprometido no período seco. A complementação hídrica com 3,5 $\mathrm{mm}$ de água de esgoto doméstico tratado por irrigação, com intervalos de 2,3; 7,0 e 14,0 promovem o maior crescimento e acúmulo de biomassa da palma forrageira orelha de elefante.

PALAVRAS-CHAVE: Irrigação. Forragem. Opuntia sp.. Reuso de água

\section{REFERENCES}

ALMEIDA, J.; PEIXOTO, C. P.; LEDO, C. A. S. Desempenho vegetativo e produtivo da palma forrageira. Enciclopédia Biosfera, Goiânia, v. 8, n. 15, p.571-581, nov. 2012.

ALVES, S. M. C.; REBOUÇAS, J. R. L.; FERREIRA NETO, M.; BATISTA, R. O.; SOUZA, L. Fertirrigação de girassol ornamental com esgoto doméstico tratado em sistema de hidroponia. Irriga, Botucatu, v. 19, n. 4, p. 714-726, Dec. 2014. https://doi.org/10.15809/irriga.2014v19n4p714

BATISTA, R. O.; SARTORI, M. A.; SOARES, A. A.; MOURA, F. N.; COSTA PAIVA, M. R. F. Potencial da remoção de poluentes bioquímicos em biofiltros operando com esgoto doméstico. Revista Ambiente \& Água, Taubaté, v. 6, n. 3, p. 152-164, Sep. 2011.

BATISTA, R. O.; REINALDO, G. P. B.; FREIRE SEGUNDO, J. M.; LEMOS FILHO, L. C. A; SILVA, P. C. M.; SANTOS, D. B. Sistema ecológico para tratamento de esgoto primário em assentamentos rurais do semiárido brasileiro. Revista Agrarian, Grande Dourados, v. 6, n. 22, p. 438-447, Dec. 2013.

BRITO, A. A. F.; FERREIRA NETO, M.; MIRANDA, N. O.; LEAL, C. C. P.; LIRA, J. F. B. Teores de nutrientes em plantas de arroz vermelho irrigado com água resíduária doméstica. Irriga, Botucatu, v. 19, n.1, p. 01-10, Mar. 2014. https://doi.org/10.15809/irriga.2014v1n1p01

COSTA, Z. V. B.; GURGEL, M. T.; COSTA, L. R.; ALVES, S. M. C.; FERREIRA NETO, M.; BATISTA, R. O. Efeito da aplicação de esgoto doméstico primário na produção de milho no assentamento Milagres (ApodiRN). Revista Ambiente e Água, Taubaté, v. 9, n. 4, p. 737-751, Dec. 2014. https://doi.org/10.4136/ambiagua. 1417

DONAGEMA, G. K.; CAMPOS, D. V. B.; CALDERANO, S. B.; TEIXEIRA, W. G.; VIANA, J. H. M. Manual de métodos de análise de solo. 2.ed. Rio de Janeiro: Embrapa Solos, 2011. 230p. (Embrapa Solos. Documentos, 132).

DUBEUX JUNIOR, J. C. B.; ARAÚJO FILHO, J. T.; SANTOS, M. V. F.; LIRA, M. A.; SANTOS, D. C.; PESSOA, R. A. S. Adubação mineral no crescimento e 77 composição mineral da palma forrageira-Clone IPA20. Revista Brasileira de Ciências Agrárias, Recife, v. 5, p. 129-135, Dec. 2010.

https://doi.org/10.5039/agraria.v5i1a591

DUBEUX JUNIOR, J. C. B.; SANTOS, M. V. F.; MELLO, A. C. L.; CUNHA, M. V.; FERREIRA, M. A.; SANTOS, D. C.; LIRA, M. A.; SILVA, M. C. Forage potential of cacti on drylands. Acta Horticulturae (ISHS), Leuven, v. 1067, n. 1, p. 181-186, Mar. 2015. https://doi.org/10.17660/ActaHortic.2015.1067.24 
EDIVAN, R. L.; FERNANDES, P. D.; CARNEIRO, M. S.; NEDER, D. G.; ARAÚJO, J. S.; ANDRADE, A. P.; QUEIROZ, J. E. Acúmulo de biomassa e crescimento radicular da palma forrageira em diferentes épocas de colheita. Revista Acadêmica: Ciências Agrárias e Ambientais, Curitiba, v. 11, n. 4, p. 373-381, Dec. 2013. https://doi.org/10.7213/academico.011.004.AO04

EMBRAPA - Empresa Brasileira de Pesquisa Agropecuária. Centro Nacional de Pesquisa de Solos. Sistema brasileiro de classificação de solos. Rio de Janeiro: EMBRAPA. 2013. 412 p.

FERREIRA, D. F. Sisvar: a Guide for its Bootstrap procedures in multiple comparisons. Ciência e Agrotecnologia, Lavras, v. 38, n. 2, p. 109-112, Apr. 2014. https://doi.org/10.1590/S1413-70542014000200001

HAO, F.; LI, J.; WANG, Z.; LI, Y. Effect of ions on clogging and biofilm formation in drip emitters applying secondary sewage effluent. Irrigation and Drainage, New York, v. 66, n. 2 p. 687-698, Apr. 2017. https://doi.org/10.1002/ird.2141

LEMOS, M.; FERREIRA NETO, M.; MEDEIROS, J. F.; DIAS, N. S.; SILVA, E. F. F. E.; LIRA, R. B. Nutritional evaluation of forage cactus fertigated with domestic sewage effluent. Revista Caatinga, Mossoró, v. 31, n. 2, p. 476-486, Jun. 2018. https://doi.org/10.1590/1983-21252018v31n224rc

LIMA, G. F. C; RÊGO, M. M. T.; AGUIAR, E. M.; SILVA, J. G. M.; DANTAS, F. D. G.; GUEDES, F. X.; LÔBO, R. N. B. Effect of different cutting intensities on morphological characteristics and productivity of irrigated Nopalea forage cactus. Acta Horticulturae (ISHS), Leuven, v. 1067. n. 1, p. 253-258, Mar. 2015. https://doi.org/10.17660/ActaHortic.2015.1067.35

QUEIROZ, M. G., SILVA, T. G. F.; ZOLNIER, S.; SILVA, S. M. S.; LIMA, L. R.; ALVES, J. O. Características morfofisiológicas e produtividade da palma forrageira em diferentes lâminas de irrigação. Revista Brasileira de Engenharia Agrícola e Ambiental, Campina Grande, v. 19, n. 10, p. 931-938, Oct. 2015. https://doi.org/10.1590/1807-1929/agriambi.v19n10p931-938

RAMOS, J. P. F.; SANTOS, E. M.; PINHO, R. M. A.; BEZERRA, H. F. C.; PEREIRA, G. A.; BELTRÃO, G. R.; OLIVEIRA, J. S. Crescimento da palma forrageira em função da adubação orgânica. Revista eletrônica de Veterinária, Malagá, v. 16, n. 12, p. 1-11, Dec. 2015.

SOUTO, J. S.; SANTOS, E. S.; DAMASCENO, M. M.; RAMOS, J. P. F.; SALES, A. T.; LEITE, M. L. M. V.; NASCIMENTO, J. P.; NASCIMENTO, J. P. Caracterização morfométrica de Opuntia ficus-indica sob diferentes arranjos populacionais e fertilização fosfatada. Tecnologia \& Ciência Agropecuária, João Pessoa, v. 5, n. 3, p. 21-26, Sep. 2011.

SILVA, L. M.; FAGUNDES, J. L.; VIEGAS, P. A. A.; MUNIZ, E. N.; RANGEL, J. H. A.; MOREIRA, A. L.; BACKES, A. A. Produtividade da palma forrageira cultivada em diferentes densidades de plantio. Ciência Rural, Santa Maria, v. 44, n. 11, p. 2064-2071, Nov. 2014. https://doi.org/10.1590/0103-8478cr20131305

SCALISI, A.; MORANDI, B.; INGLESE, P.; BIANCO, R. L. Cladode growth dynamics in Opuntia ficusindica under drought. Environmenta and Experimental Botany, Amsterdam, v. 122, n. 11, p. 158-167, Nov. 2016. https://doi.org/10.1016/j.envexpbot.2015.10.003

SOUZA, T. C.; SANTOS, M. V. F.; DUBEUX JÚNIOR, J. C. B.; LIRA, M. A.; SANTOS, D. C.; CUNHA, M. V.; LIMA, L. E.; SILVA, R. R. Productivity and nutrient concentration in spineless cactus under different fertilizations and plant densities. Revista Brasileira de Ciências Agrárias, Recife, v. 12, n. 4, p. 555-560, Dec. 2017. https://doi.org/10.5039/agraria.v12i4a5473

REGO, M. M. T.; LIMA, G. F. C.; SILVA, J. G. M.; GUEDES, F. X.; DANTAS, F. D. G.; LOBO, R. N. B. Morfologia e rendimento de biomassa da palma miúda irrigada sob doses de adubação orgânica e intensidades de corte. Revista Científica de Produção Animal, v.16, p. 118-130, 2014. https://doi.org/10.15528/21764158/rcpa.v16n2p118-130 
Growth and biomass...

AZEVEDO JUNIOR, M. S. et al.

ROCHA, R. S.; VOLTOLINI, T. V.; GAVA, C. A. T. Características produtivas e estruturais de genótipos de palma forrageira irrigada em diferentes intervalos de corte. Archivos de Zootecnia, v. 66, n. 255, p. 365-373, 2017. https://doi.org/10.21071/az.v66i255.2512 